Economics Development Analysis Journal 6(3)(2017)

\title{
Pengaruh Harga Daging Sapi Internasional, Kurs, dan GDP Per Kapita terhadap Impor Daging Sapi di Indonesia
}

\author{
Yusril Ihza ${ }^{\bowtie}$
}

Jurusan Ekonomi Pembangunan Fakultas Ekonomi, Universitas Negeri Semarang

\section{Info Artikel}

Sejarah Artikel:

Diterima April 2017

Disetujui Juni 2017

Dipublikasikan Agustus 2017

\section{Keywords:}

Internasional Beef Price,

Exchange Rate, GDP Per

Capita, Impor

\begin{abstract}
Abstrak
Penelitian bertujuan untuk menganalisis dan mengetahui faktor yang mempengaruhi impor daging sapi di Indonesia. variabel yang digunakan dalam penelitian ini adalah Harga Daging Sapi Internasional, Kurs, GDP Per Kapita dan impor daging sapi. Data yang digunakan dalam penelitian ini adalah data tahunan deret waktu dari tahun 1989 sampai dengan 2015 yang dari Kemendag, International Financial Statistik, Worldbank. Metode yang digunakan dalam penelitian ini adalah Error Correction Model (ECM) Hasil penelitian menunjukkan bahwa, dalam jangka panjang harga daging sapi internasional berpengaruh negatif dan signifikan terhadap impor daging sapi. Harga daging sapi internasional yang lebih murah daripada harga daging sapi domestik mengakibatkan konsumen lebih memilih daging sapi internasional yang telah di impor ke dalam negeri, hal tersebut mengakibatkan produk lokal tidak bisa bersaing dengan produk impor dan pasar dalam negeri dikuasai oleh negara lain. Dengan kondisi tersebut, maka saran yang diberikan oleh peneliti yaitu Pemerintah harus bersunguh-sungguh dalam memberikan kebijakan program swasembada daging sapi dan subsidi kepada peternak sapi potong di Indonesia yang selama ini belum mencapai target, sehingga pasar dalam negeri tidak dibanjiri oleh produk luar negeri dengan begitu produk dalam negeri dapat bersaing dengan produk luar negeri.
\end{abstract}

\footnotetext{
Alamat korespondensi:

ISSN 2252-6965

Gedung L2 Lantai 2 FE Unnes Kampus Sekaran, Gunungpati,

Semarang, 50229

E-mail: edaj@mail.unnes.ac.id
} 


\section{PENDAHULUAN}

Undang-undang No. 18 Tahun 2012 Tentang Pangan menyebutkan bahwa ketahanan pangan adalah kondisi terpenuhinya pangan bagi negara sampai dengan perseorangan, yang tercermin dari tersedianya pangan yang cukup, baik jumlah maupun mutunya, aman, beragam, bergizi, merata, dan terjangkau serta tidak bertentangan dengan agama, keyakinan, dan budaya masyarakat, untuk dapat hidup sehat, aktif, dan produktif secara berkelanjutan.

Ketersediaan pangan dijamin oleh negara dalam jumlah yang cukup dan terjamin mutunya bagi setiap warga negara, karena masyarakat atau warga negara pada dasarnya berhak atas ketersediaan pangan bagi keberlangsungan hidupnya. Penyediaan pangan oleh negara harus diupayakan melalui produksi pangan dalam negeri, di mana produksi oleh negara dalam penyediaan pangan harus senantiasa meningkat dari tahun ke tahun seiring dengan pertambahan penduduk dalam negara tersebut (Purwaningsih, 2008).

Negara memenuhi kebutuhan rakyatnya dalam kemandirian suatu negara merupakan indikator yang sangat penting yang harus diperhatikan, karena suatu negara yang berdaulat penuh adalah negara yang tidak tergantung dalam bidang politik, bidang keamanan, bidang ekonomi, dan sebagainya pada negara lain. Ketergantungan suatu negara dalam memenuhi kebutuhan rakyatnya dapat berbentuk ketergantungan dalam pasokan, pengambilan keputusan, teknologi, atau pola konsumsi, dan gaya hidup. Jumlah penduduk Indonesia lebih dari 210 juta orang menjadikan kondisi tersebut sangat berbahaya apabila Indonesia tidak mandiri dalam pangan. Akan tetapi perlu diketahui bahwa kemandirian pangan dalam negeri tidak berarti bahwa Indonesia akan menolak ekspor maupun impor dalam komoditas pangan, karena pada perekonomian perdagangan internasional yang menguntungkan dapat digunakan untuk menyejahterakan masyarakat di negara itu sendiri (Purwaningsih, 2008).
Pembangunan pada subsektor peternakan terus dituntut peran sertanya dalam pembangunan perekonomian nasional maupun perekonomian regional melalui sumber devisa yaitu ekspor, penyediaan bahan pangan dan bahan baku industri, pengentasan kemiskinan melalui penyediaan lapangan kerja dan peningkatan pendapatan masyarakat. Peran yang sangat penting dan strategis ini searah dengan program revitalisasi pertanian yang menempatkan kembali apa arti penting peternakan secara proporsional yang antara lain untuk mendukung dalam kecukupan dan ketersediaan pangan asal ternak (Mukson, Roessali dan Setiyawan, 2014)

Indonesia masih ketergantungan pangan dari negara lain hal tersebut dapat dilihat pada impor pangan yang masih terus terjadi dan semakin meningkat dari tahun ke tahun. Dari lima komoditas pangan utama yang diprioritaskan oleh Kementerian Pertanian menunjukkan bahwa yang selalu menjadi masalah yaitu daging sapi yang dari tahun ke tahun dari sisi ketersediaan, harga, maupun impor menjadi masalah tahunan yang saat ini belum terselesaikan.

Pemerintah lewat Menteri Pertanian mengeluarkan peraturan nomor: 19/Permentan/OT.140/2/2010 Tentang Program Swasembada Daging Sapi 2014. Program swasembada daging sapi tahun 2014 merupakan tekad bersama dan menjadi salah satu dari program utama Kementerian Pertanian. Program tersebut terkait dengan upaya mewujudkan ketahanan pangan hewani asal ternak berbasis sumber daya domestik, khususnya ternak sapi potong. Swasembada daging sapi sudah lama didambakan oleh masyarakat agar ketergantungan terhadap impor baik sapi bakalan maupun daging semakin menurun dengan mengembangkan potensi dalam negeri.

Sebelum program swasembada daging sapi 2014 dikeluarkan, program yang sama juga telah dikeluarkan oleh Pemerintah pada tahun 2000 dengan nama Program Kecukupan Daging Sapi. Program tersebut ditargetkan mencapai swasembada daging sapi pada tahun 2005. Akan 
tetapi setelah program kecukupan daging sapi tahun 2000 belum mencapai target yang diharapkan Pemerintah, program tersebut kembali diperbarui menjadi Program Percepatan Pencapaian Swasembada Daging Sapi (P2SDS) 2008-2010. Akan tetapi strategi tersebut belum mampu mengantarkan Indonesia mencapai tujuan dalam swasembada daging sapi, sehingga Pemerintah kembali melanjutkan program swasembada daging sapi dengan target pencapaian pada tahun 2014 melalui peraturan Menteri Pertanian dengan dikeluarkannya peraturan nomor:19/Permentan/OT.140/2/2010 Tentang Program Swasembada Daging Sapi 2014.

Tabel 1 Menunjukkan bahwa peningkatan produksi terjadi secara signifikan, tetapi peningkatan produksi tidak mencukupi konsumsi di Indonesia. Dapat dilihat perkembangan produksi daging sapi dari tahun ke tahun belum mampu mencukupi kebutuhan daging sapi di Indonesia. Pada tahun 2013-2016 Indonesia selalu mengalami defisit daging sapi. Pada tahun tersebut konsumsi daging sapi oleh masyarakat Indonesia mencapai rata-rata 2,61 $\mathrm{kg} / \mathrm{kapita} /$ tahun. Hal tersebut menjadikan kebutuhan daging sapi pada 2016 mencapai sebesar 674.690 ton. Dari kebutuhan nasional sejumlah itu, produksi dalam negeri hanya sebesar 441.761 ton, maka kekurangan kebutuhan nasional sebanyak 232.929 ton, sehingga kekurangan itu harus ditutup dari impor. Oleh karena itu, untuk mencukupi konsumsi masyarakat maka Pemerintah melakukan impor agar konsumsi masyarakat tercukupi. Pada tahun 2016 Pemerintah menetapkan kuota impor sebesar 232.929 ton atau setara dengan sapi hidup sebanyak 600 ribu ekor.

Tabel 1. Produksi dan Konsumsi Daging Sapi 2013-2016

\begin{tabular}{|l|l|l|}
\hline Tahun & Produksi (ribu Ton) & $\begin{array}{l}\text { Konsumsi Daging Sapi } \\
\text { (ribu Ton) }\end{array}$ \\
\hline 2013 & 403,85 & 567,31 \\
\hline 2014 & 398,14 & 595,11 \\
\hline 2015 & 405,33 & 613,11 \\
\hline 2016 & 441,76 & 674,69 \\
\hline
\end{tabular}

Sumber: Departemen Pertanian

Globalisasi yang dihadapi dunia pada saat ini menyebabkan terjalinnya bisnis berskala internasional. Bisnis internasional adalah semua transaksi yang dijalankan oleh pemerintah atau swasta yang melibatkan dua negara atau lebih. Yang termasuk di dalam bisnis internasional adalah perdagangan dan kerjasama antar negara. Indonesia tidak bisa menghindari interaksi dengan negara lain untuk memenuhi kebutuhan dalam negeri, baik untuk dikonsumsi secara langsung ataupun diolah kembali (Prafajarika, Yulianto dan Wilopo, 2014).

Dampak negatif dari kebijakan impor daging sapi yang dilakukan oleh Pemerintah yaitu menurunnya kesejahteraan petani dalam negeri. Hal ini dikarenakan harga jual daging sapi domestik akan menurun atau murah. Petani yang seharusnya mendapatkan keuntungan pada saat kondisi tingginya permintaan akan daging sapi justru mengalami kerugian. Semua kondisi ini tidak lepas dari kurangnya peranan Pemerintah dalam memperhatikan petani. Pemerintah yang seharusnya mengayomi petani dan menjaga kestabilan perekonomian terkesan tidak berpihak pada kesejahteraan para petani. Dalam hal ini Pemerintah harus lebih meningkatkan kesejahteraan para petani dan memperdulikan kestabilan perekonomian mengingat sebagian besar penduduk Indonesia bekerja sebagai petani.

Impor pada saat ini mempunyai kecenderungan didukung oleh kurs rupiah yang menguat. Hal itu dikarenakan bahwa kurs sangat 
diperlukan dalam melakukan transaksi pembayaran internasional atau keluar negeri. Jika kurs rupiah melemah maka harga daging sapi yang diimpor akan semakin mahal, tetapi jika kurs rupiah menguat maka harga daging sapi impor semakin murah. Secara teoritis, dengan merosotnya nilai tukar rupiah maka harga daging sapi impor cenderung meningkat yang berakibat berkurangnya volume impor daging sapi yang masuk, dan sebaliknya. Berdasarkan data harga daging sapi yang didapat menunjukkan bahwa dengan merosotnya nilai tukar rupiah ada kecenderungan harga daging impor semakin menurun. Keadaan tersebut menunjukkan bahwa harga daging impor merupakan harga yang dapat dipermainkan oleh negara eksportir, atau faktor lainnya, sehingga peningkatan harga (akibat depresiasi rupiah) tidak mampu menurunkan jumlah impor daging yang masuk ke Indonesia (Priyanto, 2005).

Melihat realitas sosial ekonomi masyarakat di Indonesia dan kebijakankebijakan Pemerintah seperti pembebasan masuk impor daging sapi tidak memberikan solusi yang terbaik bagi kesejahteraan petani. Upaya dalam penyediaan pangan, peningkatan ekspor, dan devisa negara tentunya akan semakin sulit tercapai. Maka kiranya perlu melakukan suatu perubahan strategi pembangunan perekonomian untuk meningkatkan kualitas, kuantitas, dan kontinuitas produksi dengan suatu ide dan gagasan perubahan yang melakukan perubahan sektor pertanian melalui perubahan strategi, kebijakan, dan program serta perbaikan kelembagaan mulai dari tingkat eksportir hingga petani. Secara bertahap, semua akan berhasil membebaskan diri dari belitan ketergantungan pangan dari negara lain. Karena sektor pertanian merupakan peluang besar dalam menunjang pembangunan perekonomian. Hal tersebut dapat menjadi lebih baik apabila didukung oleh pihak terkait, terutama Pemerintah melalui kebijakankebijakannya.

\section{METODE PENELITIAN}

Jenis data yang digunakan dalam penelitian ini adalah data sekunder yang diperoleh dari beberapa sumber dengan cara mengambil data statistik yang telah ada serta dokumen-dokumen lain yang terkait dan yang diperlukan. Penelitian ini menggunakan variabel dependen dan independen. Variabel dependen adalah variabel yang dijelaskan, sedangkan variabel independen adalah variabel yang menjelaskan. Variabel independen mempunyai sifat mempengaruhi variabel dependen, sedangkan variabel dependen tergantung dari variabel independen.

Variabel dependen dalam penelitian ini adalah impor daging sapi. Impor daging sapi yang dimaksud adalah total impor daging sapi di Indonesia yang diimpor dari berbagai negara dalam satuan ton per tahun. Data yang digunakan dalam penelitian ini adalah data impor daging sapi dari tahun 1989-2015 yang diperoleh dari comtrade.

Variabel independen dalam penelitian ini antara lain sebagai berikut:

1. Harga daging sapi internasional

Harga daging sapi internasional yaitu harga daging sapi yang terbentuk dalam pasar internasional yang disepakati oleh semua negara untuk mekanisme ekspor ataupun impor. Data yang digunakan dalam penelitian ini adalah harga daging sapi internasional dari tahun 19892015 yang diperoleh dari World Bank dengan satuan rupiah.

\section{Kurs}

Kurs adalah harga sebuah mata uang dari suatu negara yang diukur atau dinyatakan dalam mata uang lainnya. Dalam penelitian ini digunakan data nilai tukar dolar Amerika Serikat terhadap rupiah dari tahun 1989-2015 yang diperoleh dari IFS (Internasional Financial Statistik).

\section{GDP Per Kapita}

GDP Per Kapita adalah pendapatan ratarata penduduk di suatu negara yang didapatkan dari hasil pembagian pendapatan nasional suatu negara dibagi dengan jumlah penduduk negara tersebut. Data yang digunakan dalam penelitian ini adalah GDP per kapita dari tahun 1989-2015 yang diperoleh dari World Bank.

Penelitian ini menggunakan metode analisis model ECM (Error Correction Model) 
untuk mengatasi masalah regresi lacung (spurious regression) dalam data runtut waktu. Karena dengan menggunakan metode analisis ECM kita bisa menggambarkan suatu model dinamis dalam perekonomian yang berkaitan dengan waktu penelitian, baik dalam jangka panjang maupun jangka pendek, dan untuk menghindari kesalahan ekuilibrium (equilibrium error).

\section{HASIL DAN PEMBAHASAN}

Data yang bersifat runtut waktu dalam variabel untuk langkah awal estimasi model ekonomi yaitu melakukan uji stasioner pada data dengan taraf nyata sebesar 5\%. Uji stasioneritas data dapat dilakukan dengan menggunakan Augmented Dickey-Fuller (ADF) pada derajat yang sama (level atau difference) sampai data bersifat stasioner. Berdasarkan Tabel 2 menunjukan bahwa variabel penelitian tidak stasioner pada tingkat level.

Tabel 2. Hasil Uji Unit Root Test Augmented Dickey-Fuller tingkat Level

\begin{tabular}{|l|l|l|l|}
\hline \multirow{2}{*}{ Variabel } & \multicolumn{3}{|c|}{ Level } \\
\cline { 2 - 4 } & $\begin{array}{c}\text { Ajd t-stat Augmented } \\
\text { Dickey-Fuller }\end{array}$ & $\begin{array}{c}\text { nilai kritis } \\
(5 \%)\end{array}$ & \multicolumn{1}{|c|}{ Keterangan } \\
\hline HARGA_DS & -0.636 & -2.981 & Tdk Stasioner \\
\hline I & & -2.981 & Tdk Stasioner \\
\hline GURS & -1.298 & -2.981 & Tdk Stasioner \\
\hline IMPOR_DS & -1.586 & -2.981 & Tdk Stasioner \\
\hline
\end{tabular}

Data yang tidak stasioner pada tingkat level perlu dilakukan pengujian akar unit pada tingkat first difference. Sehingga dapat di lihat pada Tabel
3 bahwa keempat variabel stasioner pada tingkat first difference.

Tabel 3. Hasil Uji Unit Root Test Augmented Dickey-Fuller tingkat First Difference

\begin{tabular}{|c|c|c|c|}
\hline \multirow[b]{2}{*}{ Variabel } & \multicolumn{3}{|l|}{ First Difference } \\
\hline & $\begin{array}{l}\text { Ajd t-stat Augmented } \\
\text { Dickey-Fuller }\end{array}$ & nilai kritis $(5 \%)$ & $\begin{array}{l}\text { Keteranga } \\
\mathrm{n}\end{array}$ \\
\hline HARGA_DSI & -4.489 & -2.986 & Stasioner \\
\hline KURS & -5.258 & -2.986 & Stasioner \\
\hline GDP_PK & -4.489 & -2.986 & Stasioner \\
\hline IMPOR_DS & -4.628 & -2.986 & Stasioner \\
\hline
\end{tabular}

Uji kointegrasi digunakan untuk mengetahui hubungan jangka panjang antar variabel dalam model penelitian. Pengujian kointegrasi antara variabel bertujuan untuk mengetahui nilai residualnya terintegrasi stasioner atau tidak, apabila antar variabel terdapat kointegrasi berarti terdapat hubungan yang stabil dalam jangka panjang. Dalam uji kointegrasi ini menggunakan metode statistik Augmented Dickey-Fuller (ADF) pada derajat yang sama untuk melihat jangka panjang dapat dilihat pada Tabel 4 yang menunjukkan bahwa hasil t-statistik > nilai kritis hal tersebut dapat diartikan bahwa variabel bersifat kointegrasi atau 
bisa juga disebut bahwa variabel berpengaruh dalam jangka panjang.

Tabel 4. Hasil Uji kointegrasi

\begin{tabular}{|lr|c|l|}
\hline \multicolumn{1}{|c|}{ Persamaan Regresi } & $\begin{array}{c}\text { Nilai t- } \\
\text { statistik } \\
\text { dari } \\
\text { residual }\end{array}$ & Nilai kritis $\alpha=5 \%$ \\
\hline $\begin{array}{l}\text { Ln(IMPOR_DS) } \\
\text { f(Ln(HARGA_DSI), } \\
\text { (KURS), Ln(GDP_PK) }\end{array}$ & Ln & -5.520 & -2.986 \\
\hline
\end{tabular}

Langkah selanjutnya adalah melakukan uji asumsi klasik.

\section{Uji Asumsi Klasik}

Multikolonieritas merupakan masalah klasik yang menyatakan adanya hubungan linier antara variabel-variabel bebas yang terdapat dalam model regresi. Berdasarkan Tabel 5 hasil estimasi variabel penelitian dalam jangka panjang maupun jangka pendek diperoleh bahwa terdapat masalah multikolinieritas dalam model. Hal itu dikarenakan nilai matrik korelasi (correlation matrix) lebih dari 0,85. Akan tetapi model masih tetap digunakan untuk analisis regresi. Hal tersebut juga di sebutkan oleh (widarjono, 2013) menyatakan bahwa multikolonieritas sebagaimana kita jelaskan sebelumnya yaitu tetap menghasilkan estimator yang BLUE karena masalah estimator yang BLUE tidak memerlukan asumsi tidak adanya korelasi antar variabel independen. Multikolonieritas hanya menyebabkan kita kesulitan memperoleh estimator dengan standard error yang kecil. Masalah multikolonieritas biasanya juga timbul karena kita hanya mempunyai jumlah observasi yang sedikit. Dalam kasus terakhir ini berarti kita tidak punya pilihan selain tetap menggunakan model untuk analisis regresi walaupun mengandung masalah multikolonieritas.

Tabel 5. Hasil Uji Multikolonieritas

\begin{tabular}{|l|l|l|l|}
\hline & GDP & HARGA_DSI & KURS \\
\hline GDP & 1.00 & 0.93 & 0.89 \\
\hline HARGA_DSI & 0.93 & 1.00 & 0.96 \\
\hline KURS & 0.89 & 0.96 & 1.00 \\
\hline
\end{tabular}

Uji normalitas bertujuan untuk menguji apakah dalam model regresi, variabel pengganggu, atau residual mempunyai distribusi normal atau tidak. Penelitian estimasi jangka panjang dikatakan terbebas dari penyimpangan asumsi klasik normalitas.
Berdasarkan Tabel 6 dalam jangka panjang bahwa probabilitasnya sebesar $0,332 \mathrm{di}$ atas taraf nyata $(0,05)$ sehingga dapat dikatakan bahwa data berbebas dari penyimpangan asumsi klasik normalitas. 
Tabel 6. Uji Normalitas Jangka Panjang

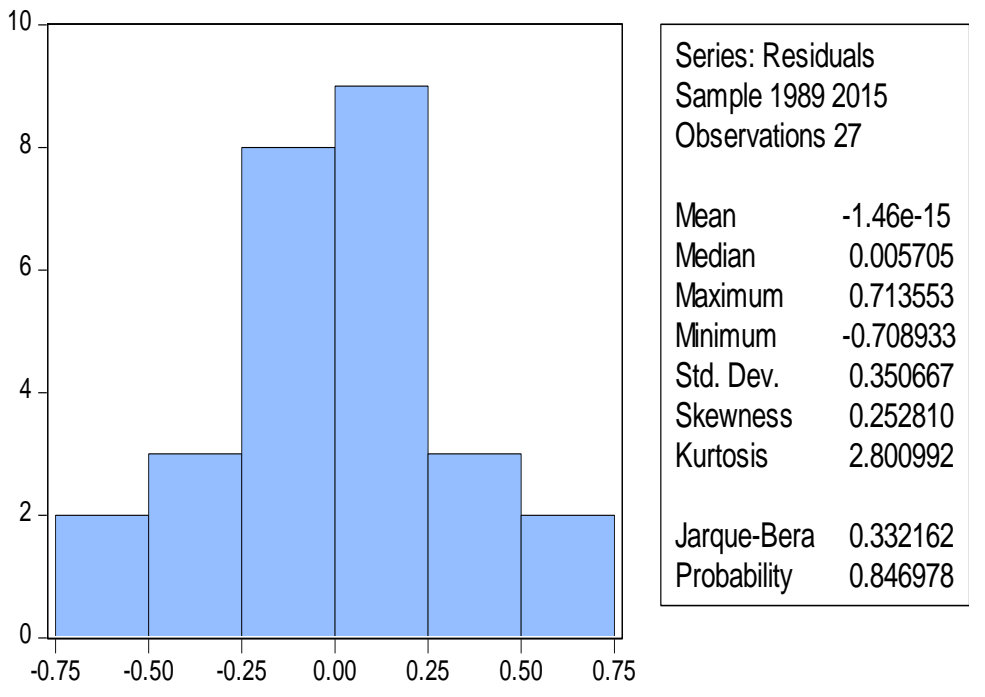

bahwa data berbebas dari penyimpangan asumsi

Berdasarkan tabel 7 dalam jangka pendek klasik normalitas.

bahwa probabilitasnya sebesar 0.758 lebih besar

dari taraf nyata $(0,05)$ sehingga dapat dikatakan

Tabel 7. Uji Normalitas Jangka Pendek

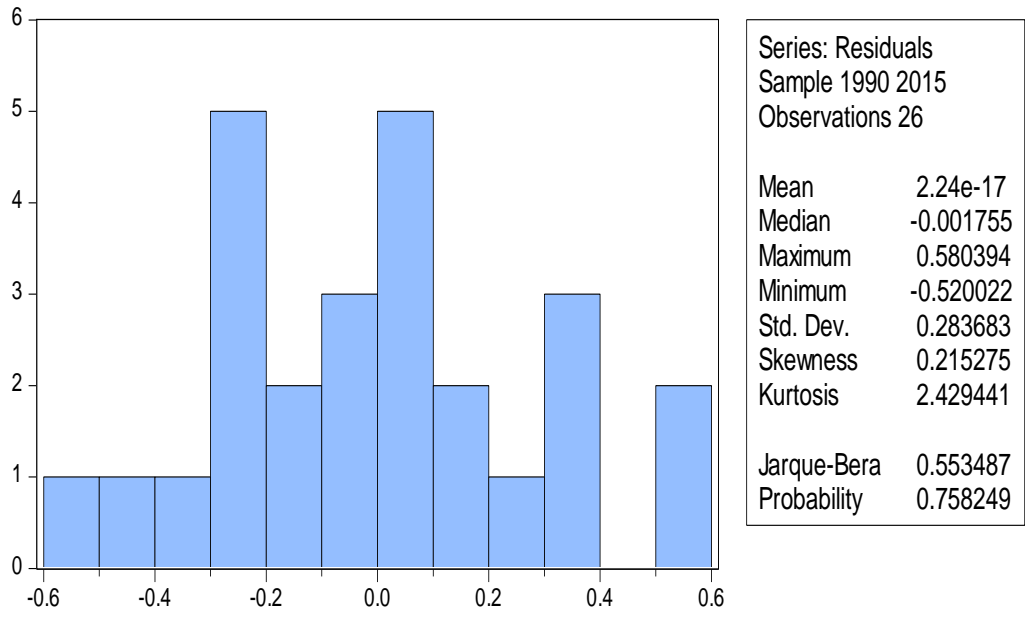

Autokorelasi merupakan korelasi antara satu variabel gangguan dengan variabel gangguan yang lain. Dalam data time series diduga sering kali mengandung unsur autokorelasi. Autokorelasi bisa positif maupun negatif, sebagian besar dari data time series menunjukkan adanya autokorelasi positif. Hal ini terjadi karena data time series seringkali menunjukkan adanya trend yang sama yaitu adanya kesamaan pergerakan naik dan turun.

Estimasi jangka panjang dalam penelitian ini terbebas dari penyimpangan asumsi klasik autokorelasi yang dibuktikan dengan uji Langgrange Multiple. Hasil uji autokorelasi probabilitasnya 0.0514 lebih besar dari taraf nyata (0.05), sedangkan jangka pendek probabilitasnya 0.1786 lebih besar dari taraf nyata (0.05), dan dapat dikatakan bahwa dalam jangka pendek maupun jangka panjang data terbebas dari penyimpangan asumsi klasik autokorelasi.

Metode untuk mendeteksi heteroskedastisitas salah satunya adalah Metode Breusch-Pagan. Dalam penelitian untuk estimasi 
jangka panjang terbebas dari penyimpangan asumsi klasik dibuktikan dengan uji BreuschPagan-Godfrey. Hasil uji heteroskedastisitas bahwa nilai probabilitasnya 0.7466 lebih besar dari taraf nyata (0.05), sedangkan pada jangka pendek nilai probabilitasnya 0.8972 lebih besar dari taraf nyata (0.05), dan dapat dikatakan bahwa dalam jangka pendek maupun jangka panjang data terbebas dari penyimpangan asumsi klasik heteroskedastisitas

Uji statistik $F$ pada dasarnya menunjukkan apakah semua variabel independen yang dimasukkan dalam model mempunyai pengaruh secara bersama-sama atau simultan terhadap variabel dependen. Dengan uji $\mathrm{F}$ ini dapat diketahui apakah variabel bebas mempengaruhi variabel terikat secara bersamasama. Dapat dilihat dari probabilitas estimasi jangka panjang di bawah taraf nyata (0.05) maka dapat diketahui bahwa dalam model mempunyai pengaruh secara bersama-sama atau simultan terhadap variabel dependen.

Hasil dari koefisien determinasi jangka panjang dapat dilihat dari Tabel 8 menunjukkan bahwa nilai R-square sebesar 0.935 atau sebesar 92, dapat diartikan kemampuan variabel $\mathrm{X}$ atau variabel independen untuk menjelaskan variabel $\mathrm{Y}$ atau variabel dependen sebesar $92 \%$ dan sebesar $8 \%$ dipengaruhi oleh faktor lain.

Tabel 8. Koefisien Determinasi

\begin{tabular}{|c|c|}
\hline $\begin{array}{c}\text { R- } \\
\text { squared }\end{array}$ & Adjusted R-squared \\
\hline 0.935 & 0.927 \\
\hline
\end{tabular}

Hasil dari koefisien determinasi jangka pendek dapat di lihat pada Tabel 9. yang menunjukkan bahwa nilai R-square sebesar 0.609 atau sebesar 60, dapat diartikan kemampuan variabel $\mathrm{X}$ atau variabel independen untuk menjelaskan variabel $\mathrm{Y}$ atau variabel dependen sebesar $60 \%$ dan sebesar $40 \%$ dipengaruhi oleh faktor lain.
Tabel 9. Koefisien Determinasi

\begin{tabular}{|l|c|}
\hline R-squared & $\begin{array}{c}\text { Adjusted R- } \\
\text { squared }\end{array}$ \\
\hline 0.609 & 0.534 \\
\hline
\end{tabular}

Intepretasi dari hasil regresi menunjukkan pengaruh variabel independen harga daging sapi internasional, kurs, dan GDP perkapita terhadap variabel dependen impor daping sapi.

\section{Intepretasi Harga Daging Sapi Internasional}

Variabel harga daging sapi internasional berpengaruh negatif dan signifikan terhadap impor daging sapi. Dalam jangka panjang dapat dilihat bahwa koefisien variabel harga daging sapi internasional sebesar -2.695dengan tstatistik -6.259 lebih besar t-tabel yaitu 1.706 . Sedangkan pada jangka pendek harga daging sapi internasional mempunyai hubungan yang negatif tidak signifikan.

Hal ini dikarenakan tinggi rendahnya permintaan impor daging sapi dipengaruhi oleh harga barang itu sendiri. Seperti dijelaskan pada hukum permintaan ketika harga naik maka jumlah barang yang diminta akan mengalami penurunan, hal tersebut sesuai dengan hasil dari penelitian yang menjelaskan bahwa ketika harga daging sapi naik sebesar $1 \%$ maka jumlah impor daging sapi mengalami penurunan sebesar -2.695 . Temuan itu juga didukung oleh penelitian terdahulu yang dilakukan oleh (Prafajarika, Yulianto dan Wilopo, 2014).

\section{Intepretasi Kurs}

Variabel kurs berpengaruh positif dan signifikan terhadap impor daging sapi. Dalam jangka panjang dapat dilihat bahwa koefisien variabel kurs sebesar -1.981dengan t-statistik 4.998 lebih besar t-tabel 1.706 . Sedangkan pada jangka pendek kurs mempunyai hubungan yang positif tidak signifikan.

Berdasarkan teori kurs mempunyai hubungan negatif terhadap impor. Ketika kurs rupiah mengalami depresiasi maka akan 
mengakibatkan harga barang impor menjadi mahal dan impor menurun, sedangkan pada penelitian ini tidak sesuai dengan teori. Akan tetapi peneliti menemukan alasan mengapa kurs berpengaruh positif terhadap impor, yaitu ketika kurs rupiah mengalami depresiasi tidak mengurangi impor barang ke dalam negeri hal tersebut dikarenakan pada kondisi negara Indonesia yang masih kekurangan banyak akan daging sapi maka kekurangan itu ditutup dengan impor. Pada kenyataannnya walaupun kurs terdepresiasi yang menjadikan harga daging sapi internasional mengalami kenaikan akan tetapi kenaikan harga daging sapi internasional tersebut masih di bawah harga daging domestik. Sehingga dengan permintaan akan daging sapi di Indonesia yang tinggi, maka negara Indonesia tetap melakukan impor daging sapi walaupun kurs mengalahami pelemahan. Temuan itu juga didukung oleh (Prafajarika, Yulianto dan Wilopo, 2014).

\section{Intepretasi GDP Per Kapita}

Variabel GDP per kapita berpengaruh positif dan signifikan terhadap impor daging sapi. Dalam jangka panjang dapat dilihat bahwa koefisien variabel GDP per kapita sebesar 1.621 dengan t-statistik 9.917 lebih besar t-tabel 1.706 dapat diartikan bahwa ketika GDP per kapita mengalami kenaikan sebesar $1 \%$ maka akan berpengaruh terhadap impor daging sapi di Indonesia mengalami peningkatan sebesar 1.621834. Sedangkan pada jangka pendek dapat dilihat bahwa koefisien variabel GDP per kapita sebesar 3.046406 dengan t-statistik 2.295043 lebih besar t-tabel 1.706 dapat diartikan bahwa ketika GDP per kapita mengalami kenaikan sebesar $1 \%$ maka akan berpengaruh terhadap impor daging sapi di indonesia mengalami peningatan sebesar 3.046406. Hal ini dikarenakan tinggi rendahnya permintaan impor daging sapi dipengaruhi oleh pendapatan masyarakat Indonesia. Permintaan akan daging sapi dipengaruhi daya beli masyarakat dimana hanya seseorang yang berpendapatan tinggi yang mau dan mampu membeli daging sapi. Hal tersebut juga didukung oleh teori ekonomi keynes yang menjelaskan adanya hubungan antara pendapatan yang diterima saat ini (pendapatan disposable) dengan konsumsi yang dilakukan saat ini juga. Dengan kata lain, pendapatan yang dimiliki dalam suatu waktu tertentu akan mempengaruhi konsumsi yang dilakukan oleh manusia dalam waktu itu juga Apabila pendapatan meningkat maka konsumsi yang dilakukan juga akan meningkat, begitu pula sebaliknya.

\section{SIMPULAN}

Hasil dari penelitian dengan metode error correction model dari penelitian tentang faktor-faktor yang mempengaruhi impor daging sapi di Indonesia pada tahun 1989-2015 di dapatkan kesimpulan sebagai berikut:

Hasil penelitian menunjukkan bahwa secara parsial dalam jangka panjang harga daging sapi internasional berpengaruh terhadap impor daging sapi di Indonesia. Berdasarkan hasil yang diperoleh maka $\mathrm{H} \_1$ diterima sehingga harga daging sapi internasional mempunyai hubungan negatif dan signifikan terhadap impor daging sapi di Indonesia, sedangkan dalam jangka pendek harga daging sapi internasional tidak berpengaruh terhadap impor daging sapi di Indonesia.

Hasil penelitian menunjukkan bahwa secara parsial dalam jangka panjang kurs berpengaruh terhadap impor daging sapi di Indonesia. Berdasarkan hasil yang diperoleh maka $\mathrm{H} \_2$ ditolak sehingga kurs mempunyai hubungan positif dan signifikan terhadap impor daging sapi di Indonesia. Sedangkan dalam jangka pendek kurs tidak berpengaruh terhadap impor daging sapi di Indonesia.

Hasil penelitian menunjukkan bahwa secara parsial dalam jangka panjang maupun jangka pendek GDP per kapita berpengaruh terhadap impor daging sapi di Indonesia. Berdasarkan hasil yang diperoleh maka H_3 diterima sehingga GDP per kapita mempunyai hubungan positif dan signifikan terhadap impor daging sapi di Indonesia.

Hasil penelitian menunjukkan bahwa dalam jangka panjang maupun jangka pendek variabel harga daging sapi internasional, kurs, 
GDP per kapita secara bersama-sama berpengaruh terhadap impor daging sapi di Indonesia.

Indonesia sebagai suatu negara sangat berbahaya apabila tidak mandiri dalam pangan. Impor merupakan salah satu solusi dalam pemenuhan kekurangan pangan di dalam negeri. Peran impor dari tahun ke tahun semakin besar terhadap perekonomian di Indonesia. Akan tetapi dengan impor yang berlebihan mengakibatkan buruknya perekonomian di dalam negeri, karena impor merupakan kebocoran pendapatan dan menjadikan terpuruknya produk lokal dalam negeri.

Produktifitas daging sapi dalam negeri yang belum mampu mencukupi kebutuhan konsumsi atau permintaan akan daging sapi dalam negeri menyebabkan Pemerintah menjadikan impor daging sapi untuk memberikan solusi dalam kurangnya permintaan daging sapi dalam negeri tersebut. Akan tetapi impor daging sapi yang telah dilakukan selama ini menimbulkan masalah. Sebaiknya impor daging sapi harus ditekan karena menjadikan produksi daging sapi dalam negeri tidak berkembang dan menjadikan harga daging sapi dalam negeri menjadi tidak stabil.

Berdasarkan hasil penelitian, dalam jangka panjang harga daging sapi internasional berpengaruh negatif dan signifikan terhadap impor daging sapi. Harga daging sapi internasional yang lebih murah daripada harga daging sapi domestik mengakibatkan konsumen lebih memilih daging sapi internasional yang telah di impor ke dalam negeri, hal tersebut mengakibatkan produk lokal tidak bisa bersaing dengan produk impor dan pasar dalam negeri dikuasai oleh negara lain. Dengan kondisi tersebut, maka saran yang diberikan oleh peneliti yaitu Pemerintah harus bersunguh-sungguh dalam memberikan kebijakan program swasembada daging sapi dan subsidi kepada peternak sapi potong di Indonesia yang selama ini belum mencapai target, sehingga pasar dalam negeri tidak dibanjiri oleh produk luar negeri dengan begitu produk dalam negeri dapat bersaing dengan produk luar negeri.

\section{DAFTAR PUSTAKA}

Departemen pertanian. (2016). Basis Data. http://www.deptan.go.id

Mukson. Roessali, W. \& Setiawan. (2014). Analisis Wilayah Pengembangan Sapi Potong dalam Mendukung Swasembada Daging. Jurnal Peternakan Indonesia, Vol. 16 (1).

Peraturan Mentri Pertanian Nomor : 19/Permentan /OT.140/2/2010 Tentang Program Swasembada Daging Sapi 2014

Prafajarika, S.W. Yuliyanto, W \& Wilopo. (2014). Pengaruh Nilai Tukar, Harga dalam Negeri dan Harga Internasional Terhadap Volume Impor Daging Sapi Indonesia. Jurnal Administrasi Bisnis

Purwaningsih, Yunastiti. (2008). Ketahanan Pangan: Situasi, Permasalahan, Kebijakan dan Pemberdayaan Masyarakat. Jurnal Ekonomi Pembangunan. Vol. 9, No. 1.

Priyanto, Dwi. (2005). Evaluasi Kebijakan Impor Daging Sapi Melalui Analisis Penawaran dan Permintaan. Bogor: Balai Penelitian Ternak, 276.

Undang-undang No.18 Tahun 2012 Tentang Ketahanan Pangan.

Widarjono, Agus. (2009). Ekonometrika Pengantar dan Aplikasi. Yogyakarta. 